\title{
Balancing Economy and COVID 19
}

\author{
Sukhman Walia ${ }^{1}$, Dr. Swaroopa Chakole ${ }^{2}$ \\ ${ }^{1}$ Intern, Dept. of Community Medicine, Jawaharlal Nehru Medical College, Datta Meghe Institute of Medical \\ Sciences (Deemed to be University), Sawangi (Meghe), Wardha-442001, Maharashtra, India \\ ${ }^{2}$ Professor, Dept. of Community Medicine, Jawaharlal Nehru Medical College, Datta Meghe Institute of \\ Medical Sciences (Deemed to be University), Sawangi (Meghe), Wardha-442001, Maharashtra, India \\ Email: ${ }^{1}$ bswlew@
}

Corresponding author's name and address: Dr. Swaroopa Chakole, Department of Community Medicine, Acharya Vinoba Bhave Rural Hospital, Datta Meghe Institute of Medical Sciences (DU).

Corresponding author's email id: drswaroopachakole@gmail.com

Type of Article: Review

Conflict of Interest: None

Funding: DMIMS

Ethical Approval: IEC, DMIMS, Wardha.

\section{ABSTRACT \\ BACKGROUND}

COVID-19 or coronavirus disease 2019 has multispectral consequences attached to it. Economic downturn is one of them. Almost all countries are facing economic challenges post covid-19 and are searching for panacea.

\section{SUMMARY}

Along with the medical impact which has resulted into almost more than 85 million infection of COVID-19 worldwide and almost two million case fatalities, there is also economic downfall attached to it. After the great depression of 1930, the pandemic induced crisis is worst in almost past hundred years. Even the basic needs of human beings such as food was not able to fulfil after pandemic. The prolonged lockdown to contain the viral spread of novel coronavirus made almost all the economic activities closed leading to widespread loss of livelihood and jobs. GDP outputs were contracted and demand also soared due to saving nature of people in uncertain times.

\section{CONCLUSION}

As the vaccine is in final stage and is ready to be distributed, more and more businesses can restart. Policy makers should not shy away from providing any fiscal package if necessary, to revive the economy.

KEYWORDS: COVID-19, ECONOMY, INDIA, MUTATION, FOOD SECURITY, UNEMPLOYMENT.

\section{INTRODUCTION}

COVID-19 or coronavirus disease 2019 is wreaking havoc all over the world. One year hence and still the uncertainty attached to the disease outcome is there and no on can predict the trajectory of the disease course. The high virulent nature and lethal capacity makes it the most dangerous disease outbreak and a grave challenge in front of humanity as a whole. As of January 16, 2021, 93,819,952 people has been infected by COVID-19 and 2,008,273 case fatalities has been reported due to COVID-19 complications crossing the unfortunate mark of two million(1). The World Health Organization (WHO) was forced to declare the COVID-19 as pandemic which is the only event since the inception of the organization(2). United States of America, India, Brazil, Russian federation, France and United Kingdom are the top countries having more than half of infected cases and case fatalities around the world(3). The new strain which is the mutated form of novel coronavirus has been reported from United Kingdom and South Africa which already raised concern as it is supposedly 70 percent more virulent than current strain(4). The impact on the economy is huge and it going to persist for considerable amount of time. Various mitigation measures were behind 
the slowdown in the economy. Some impacts are graver and needs more attention. After the vaccine arrival, chances of economic bounce back are high and all the steps must be taken in order to ensure quick revival of the economy. In this article a comprehensive overview has been taken to take a stalk on current and future economic course.

\section{COVID-19 AND FOOD SECURITY CRISIS}

COVID-19 or coronavirus disease 2019 has multispectral impact encompassing nearly all factors of the human life. Still the pandemic of COVID-19 is evolving and only a few visible impact has been felt.(5) But there are lot of other impact which are going to be unearthed in coming few days. Talking of COVID-19 pandemic and its impact on human society as whole, food security and looming food crisis is a must to discuss about. Food is one of the basic necessities of man among others like shelter and clothes. Without the food security, human civilization will not last long. Also, sustainability in the practices followed in food production will play a major role in near future. But coronavirus disease 2019 has played a distant role in disturbing the food production and distribution process along with consumption of the same. COVID-19 posed a major threat to food security as various attached factors made it difficult to continue the production and distribution of food(6). The economic downturn and disruption in supply chain of food and consumables needs to address and is being addressed all over the world by governmental agencies. After the declaration of COVID-19 as pandemic by World Health Organization (WHO), there was a serious dilemma in front of policy makers whether to choose the containment of the coronavirus option or to allow agricultural practices which provides food to many poor and hunger-stricken people all across the globe. Also, not all the food stuffs are produced in one country alone and there is always a trade ongoing to fulfill the each other's need. The pandemic has been successful in halting this trade and leaving hundreds and thousands of people in vulnerable condition. Immediately after the COVID-19 as pandemic by WHO, many countries resorted to the lockdown and movement restriction option as no other feasible option was on the table. Nationwide lock down was imposed all across the globe from the month of March, 2020, and people were left stranded wherever they were at the time of lockdown announcement. This was done in order to curb the spread of the coronavirus which had showed its lethal nature in china already. Therefore countries wanted to isolate and treat the already infected patients that has come from abroad and wanted to stop the spread at initial stage(7). This harsh measure closed down every job and work, economic activity was forced shut except some essential services such as health care services and law enforcement services. Agricultural related activities were also closed down and agricultural laborers were not able to work and distribution of the supplies was also hit as they were confined to their places as movement restrictions was imposed. Although no major food shortage was reported but there was undercurrent about the uncertainty attached with the pandemic. Economic activities were almost completely shut down and agricultural input supplies were stopped. The worst hit among the agricultural sector was daily laborers which works in agricultural fields. They have no land and they toil others land in return of some grains and food stuffs which they bring home to fulfill their family's hunger. In lockdown there was no such option available. Many countrieshave imposed export restrictions owing to the attached uncertainty about the coronavirus disease 2019 and its fallout. This has created the 
shortages of food supplies mostly of staple foods such as rice, wheat and coarse grains in many countries. All pillars of security of food which ensures the safe and minimum consumption of food items that humans need to survive has been affected. This includes availability, accessibility, utilization, stability. Other fall out of the COVID-19 in terms of food are consumption of course and cheap foods which are less nutritious as lots of people lost their livelihood and jobs, prices instability attached which also created artificial hoarding of the grains by antisocial elements of the society to seek more profit. The pandemic which was initially a global health crisis was being turning into global food crisis(8). It is very important to maintain the food security during the health crisis. The pandemic has induced income loss and loss of jobs and livelihood affecting the purchasing power of the people. Also access to the food items was also the problem and supply chain disruption linked to movement restrictions played a major role in aggravating the problems. Millions of people were already on the brink of starvation and cute hunger due to various ongoing reasons. The pandemic has added several millions to it. According to the World Food Program, which recently got Nobel Prize for peace for the year 2020, said that additional 170 million people can push to extreme poverty hunger after the pandemic has struck. This was estimated mainly due to the job losses and loss of livelihood. The situation was grave that many countries have to start social security scheme just after the pandemic and food delivery through public distribution system to ensure the sustenance of the people. Buffer stocks of food grains were made open for all to those demanding it despite any documentation. This has provided some comfort on food security factor and people can at least have their meal.

\section{COVID-19 AND MICRO AND MACRO-ECONOMIC IMPACT}

The COVID-19 pandemic is neither the first nor the last pandemic that had or will strike the globe of earth. In fact, many pandemics has occurred way before the coronavirus disease 2019 pandemic and had multispectral impact on the lives of the human being. For example, the last pandemic which caused such widespread disruption was Spanish flu which struck the world in 1918-1920. It had caused tremendous damages in terms of human lives and wealth. But the assessment of the pandemic is difficult as little documentation is available about that pandemic. There are several direct and indirect impacts associated with the pandemics like COVID-19. The immediate impact which is induced by COCID-19 induced lockdown is that it affects the consumption of goods and services and disrupts the ongoing process. Also, the duration and tenure of the pandemic plays a crucial role in deciding whether after the pandemic economy will resurrect quickly or will be sluggish for considerable amount of time. Non-pharmacological interventions like physical distancing and cap on amount of people in certain unit area affects the efficiency of the people and hinders with the profitability of the any economic activity(9). Any entrepreneurial or economic activity is undertaken by any human is based on its future prospects about making profits. This requires efficient management of the available land,labor and capital which will reap him or her good benefits. But artificial restrictions like these will make business not feasible and this will affect the income levels of the workers. Also, sluggish demand also lowers the output of any industrial unit which also leads to loss of jobs. People like to spend less and save more in such times of crisis and demand weakens over the period of time. A vicious cycle of low demand and less supply starts to operate and it needs an external push 
either from governmental policies like fiscal measures or monetary policies or huge private investment. Supply side disruptions makes the lives even worse and creates the artificial shortage of the goods for which customers have to pay more for same quantity. This may induce rise in inflation levels despite low demand(10). Unemployment and drop in standard of living are the prominent outcome which has its own consequences on various other sectors. The uncertainty attached to such events make people even skeptical about their new investment plans. Investors are worried and hence choose less risky options of depositing their money to banks which will definitely return the cost. As new investments are hampered, expansion of the industries does not take place and current units are already shut down resulting in sharp decline in gross domestic product of any region and country. Now a days, no economic unit is isolated and economies around the world are so interconnected that even one fallout among the linkage can have cascading effects on other factors(11).

\section{IMPACT ON WORLD ECONOMY}

Lockdown induced closure of economies and industries has completely stopped the output of the commodities and products. There was expected a sharp fall in output of the companies and industrial set up. In fact, certain economies like India imposed such harsher lockdown that whole country was stopped resulting in major losses of domestic product. As India and several likewise countries influence the world growth figures, the growth rate of gross domestic product of all economies was bound to fall. International monetary funds (IMF) have projected in May 2020 that world economy will shrink by more than 3 percent. Which is a huge figure and will have massive cascading impact. The slowdown that is experienced by the world is steepest since the great depression and surpassed thefall of 2008 subprime crisis that had struck the world. Lockdown was enforced so as to flatten the curve of the COVID-19 infection cases but it was definitely successful in flattening the growth trajectory of economies around the world(12). Global economy was forced to be in recession due to this unprecedented closure of economic activities. More than quarter of the working age population was forced to sit at home as unemployment risen to high levels. 2008 financial crisis has lot to offer in terms of how to tackle the economic fallout induced by COVID19 butfinancial setback by COVID-19 is many times bigger than the 2008 global economic crisis. United States of America, the world's largest economy and have interconnections with major economies around the world is projected to shrink by 5.9 percent. Same fate is projected to be followed by top economies around the world such as Japan, United Kingdom, Germany and France. They are projected to contract by 5.2, 6.5, 7, and 7.2 percent respectively. Advanced economies were hit harder and together they areprojected to contract by almost 6 percent. Most hit countries of Europe's such as Italy and Spain had experienced their worst nightmare coming true. Their gross domestic product (GDP) will contract by 17.5 and 19.2 percent owing to lockdown and massive case infection of COVID-19. Industry wise losses are differential in nature as some of them experienced harsher impact of COVID-19 than others due to various reasons. Oil and natural gas sector were bound to affect as lockdown was imposed and people were made to sit at home resulting in less or no domestic and international travel. Massive drop in prices were experienced and which is also a labor intensive sector which further resulted in widespread job loss as it was not feasible to run the company(13). Many gulf countries, where most of the oil is explored and extracted had sent back their expat population which was mainly employed in oil and natural gas sector. 
These people belong to high population density region of the world such as south Asia and sends huge remittances to their home nation to support their families and also support the countries forex reserve and trade balance. Another worst hit sector was aviation sector. Almost all countries halted all types of flights from any outside countries as the scare of theCOVID-19 was huge. The massive virulent nature and case fatalities has prompted this measure. This impacted various other sectors such as oil and natural gas sector, travel and tourism sector which have intimate relationship with each other. Till date the aviation sector has not been able to cope up with the pressure and majority of the aircrafts are grounded. These are all labor intensive sectors and any adverse impact on these sector will have magnifies negative impacts multiple lives are dependent on it(14).

\section{COVID-19 IMPACT ON INDIAN ECONOMY}

The impact on Indian economy of the COVID-19 induced events is spectacular is India stands at third position in terms of purchasing power parity terms and 6 places in terms of nominal GDP. Impact on India's economy has watchers across the globe as it is the emerging economy with huge market potential. Investor sentiments are positive for India as it is poised to become the world largesteconomy at the end of this century. Serval credit ratings agencies such as Moody's and S\&P and many more have downgraded the ratings of almost all major emerging economies including India. In fact, India is one step above the junk category of investment destination. But the future prospects attached to it makes it the favorable destination for investors. India was experiencing the slowdown in economy even before the pandemic arrived. In fact eight quarters prior to the arrival of the COVID-19 pandemic, there was slowdown experienced and pandemic has acted as magnifying agent in terms of economic downturn(15-17). In India too, sectors like aviation, tourism, travel and hospitality have been booming before COVID-19 and employed the major chunk of the population. But after the lockdown induced by the COVID-19, all these sectors have been experiencing the worst phase in almost last ten years. Hotel bookings declined by almost 70 to 90 percentage. A hoax about the possible transmission through poultry products has brought down the rates of the meat tremendously, practically selling at no cost. The international crude prices such as of western Texas intermediate (WTI) and Brent crude has fallen to considerable amount. India, a one of the biggest importer of crude oil experienced some breather there(18-20). Oil dependentsectors such as paints, specialty chemicals, PVC pipes, cements got some maneuvering area as their input cost got reduced. The country's central bank that is Reserve Bank of India, was continuously slashing rates up till last bi monthly review then decided to stop the rate slashing as it was attached to rising inflation which puts the countries premier bank at dilemma situation. Although IMF has lauded the efforts taken by Indian government in reviving the economy, more can be done in order to bring back the growth. Investor sentiments are positive about the emerging and one of the biggest markets and more and more industries are eying for catching up the market(21-23). Unemployment is still the top most issue and if solved can have cascading positive effects. The grim situation can be seen from the fact that whole year's subscription was availed by job seekers in rural employment guarantee scheme which assures of minimum assured wages for certain days of work. Many white-collar professionals were applying for daily wagers job. The pandemic was proved to boon for health care spending as all the resources were diverted to the containment of the virus. This will reap 
benefits in future as the hospitals are now having better infrastructure(17). Many studies have reflected on the considerable Positive effects of Covid-19 (24-26).

\section{CONCLUSION}

As the pandemic induced lockdown is slowly easing up and economies are trying to revive, all the necessary steps must be taken to ensure their resurrection. As the vaccine rollout has been started in various countries, particularly in India, confidence boosting measures should be undertaken so as to drive out the wheel of the economy from the mud of slowdown. Fiscal stimulus along with basic one time pay to all can be some of the options. Food is the basic necessity and must be fulfilled in any circumstances. It is the duty of state to ensure that no one sleeps empty stomach. Various schemes launched to ensure minimum food for all post lockdown must be continued and reviewed as effects of the pandemic has not completely waned away. As travel restrictions are loosening up, labor intensive sectors such as travel and tourism, industries and businesses must be kick started as these can have cascading effect in the form of generating demands which lacking now. Coronavirus is here to stay for a while and we need to operate with it but with proper precaution. Vaccine will be delivered and then full-fledged recovery can be expected. Various new avenues left opened by covid-19 pandemic must be explored and possible opportunities from it can be cashed in. Finally, decentralization of industries from urban centric to many tier two, tier three cities can be done in order to make them self-reliant. Import dependency must be diversified as depending on any one nation may prove disastrous. Job creation should be topic for focus as unemployment levels are unprecedented. Solving this problem will solve many other problems like lack of demand, speedy recovery and so many other things. For solving the unemployment problem, urban employment guarantee scheme can be run on the trajectory of rural counterpart. As the money will float, the demand will pick up automatically, which will revive the industry and the wheel of the economy will kick start again.

\section{REFERENCES}

[1] COVID-19 Map [Internet]. Johns Hopkins Coronavirus Resource Center. [cited 2021 Jan 16]. Available from: https://coronavirus.jhu.edu/map.html

[2] WHO Director-General's opening remarks at the media briefing on COVID-19 - 11 March 2020.pdf.

[3] WHO Coronavirus Disease (COVID19) Dashboard [Internet]. [cited 2021 Jan 16]. Available from: https://covid19.who.int

[4] Wise J. Covid-19: New coronavirus variant is identified in UK. BMJ [Internet]. 2020 Dec 16 [cited 2020 Dec 23];371:m4857. Available from: https://www.bmj.com/content/371/b mj.m4857

[5] Dushyant Bawiskar, Pratik Phansopkar, Ayurva Vilas Gotmare. COVID-19 Facets: Pandemics, Curse and Humanity. Int J Res Pharm Sci. 2020 Aug 6;11(SPL1):385-90.

[6] Laborde D, Martin W, Swinnen J, Vos R. COVID-19 risks to global food security. Science [Internet]. 2020 Jul 31 [cited 2021 Jan 14];369(6503):500-2. Available from:

https://science.sciencemag.org/conte $\mathrm{nt} / 369 / 6503 / 500$

[7] Brodeur A, Gray D, Islam A, Bhuiyan SJ. A Literature Review of the Economics of COVID-19. 2020;63.

[8] An economist explains what COVID-19 has done to the economy [Internet]. World Economic Forum. [cited 2021 Jan 14]. Available from: https://www.weforum.org/agenda/20 
20/09/an-economist-explains-whatcovid-19-has-done-to-the-globaleconomy/

[9] Chudik A, Mohaddes K, Pesaran MH, Raissi M, Rebucci A. Economic consequences of Covid-19: A counterfactual multi-country analysis [Internet]. VoxEU.org. 2020 [cited 2021 Jan 14]. Available from: https://voxeu.org/article/economicconsequences-covid-19-multicountry-analysis

[10] Pak A, Adegboye OA, Adekunle AI, Rahman KM, McBryde ES, Eisen DP. Economic Consequences of the COVID-19 Outbreak: the Need for Epidemic Preparedness. Front Public Health [Internet]. 2020 [cited 2021 Jan 14];8. Available from: https://www.frontiersin.org/articles/1 0.3389/fpubh.2020.00241/full

[11] Roy S. ECONOMIC IMPACT OF COVID-19 PANDEMIC. Tech Rep. 2020;21.

[12] Chaudhary M, Sodani PR, Das S. Effect of COVID-19 on Economy in India: Some Reflections for Policy and Programme. J Health Manag [Internet]. 2020 Jun 1 [cited 2021 Jan 14];22(2):169-80. Available from: https://doi.org/10.1177/09720634209 35541

[13] Beyer RCM, Franco-Bedoya S, Galdo V. Examining the Economic Impact of COVID-19 in India through Daily Electricity Consumption and Nighttime Light Intensity. :36.

[14] Mou J. Research on the Impact of COVID19 on Global Economy. IOP Conf Ser Earth Environ Sci [Internet]. 2020 Aug 12 [cited 2021 Jan 14];546:032043. Available from: https://iopscience.iop.org/article/10.1 088/1755-1315/546/3/032043

[15] Socio-economic impact of COVID19 [Internet]. UNDP. [cited 2021 Jan 14]. Available from: https://www.undp.org/content/undp/e n/home/coronavirus/socio-economicimpact-of-covid-19.html

[16] Ozili P, Arun T. Spillover of COVID-19: impact on the Global Economy. SSRN Electron J. 2020 Mar 27;

[17] Nicola M, Alsafi Z, Sohrabi C, Kerwan A, Al-Jabir A, Iosifidis C, et al. The socio-economic implications of the coronavirus pandemic (COVID-19): A review. Int J Surg Lond Engl. 2020 Jun;78:185-93.

[18] Agrawal, D., N. Khara, B. Mundada, N. Bhola, and R. Borle. "COVID-19 and Its Financial Effects on the Dental Fraternity and Health-Care Workers: A Literature Review." International Journal of Research in Pharmaceutical Sciences 11, no. Special Issue 1 (2020): 628-31. https://doi.org/10.26452/ijrps.v11iSP L1.2883.

[19] Khatib, M.N., S. Gaidhane, M. Khatib, M. Ahmed, A. Gaidhane, and Z.Q. Syed. "SARS-CoV and SARSCoV-2: Similar Viruses with Different Trajectories." Wutan Huatan Jisuan Jishu 16, no. 5 (2020): 544-48.

[20] Budhrani, A.B. "A Review: Coronavirus, Its Types, and Impact of Covid-19 on Global Wealth." International Journal of Research in Pharmaceutical Sciences 11, no. Special Issue 1 (2020): 455-61. https://doi.org/10.26452/ijrps.v11iSP L1.2811.

[21] Chaudhari, B.V., and P.P. Chawle. "Life Lessons of the Pandemic "COVID-19"." International Journal of Research in Pharmaceutical Sciences 11, no. Special Issue 1 (2020): 469-71. https://doi.org/10.26452/ijrps.v11iSP L1.2814.

[22] Patil, D., and W.M. Naqvi. "COVID19 and Education System: Impact of Current Pandemic on Adaptive Learning Strategies in Medical 
Education System." International Journal of Research in Pharmaceutical Sciences 11, no. Special Issue 1 (2020): 403-6. https://doi.org/10.26452/ijrps.v11iSP L1.2736.

[23] Rathi Saurabh, D., P. Nikhade, N. Motwani, S. Baror, and A. Jaiswal. "Coronavirus Pandemic-the Real Lessons Are Learnt in the Time of Crises." International Journal of Research in Pharmaceutical Sciences 11, no. Special Issue 1 (2020): 101114.

https://doi.org/10.26452/ijrps.v11iSP L1.3426.

[24] Bakshi, S., V. Toshniwal, A. Agrawal, S. Acharya, and S. Shukla. "Awareness and Psychosocial Effects of Covid-19 Pandemic on Health Care Professionals and Medical Students across the State of Maharashtra." International Journal of Current Research and Review 12, no. 22 Special Issue (2020): S-122-S125.

https://doi.org/10.31782/IJCRR.2020 .SP74.

[25] Borage, S., and P. Shelotkar. "Positive Effects of Covid-19 on Earth." International Journal of Research in Pharmaceutical Sciences 11, no. Special Issue 1 (2020): 23438.

https://doi.org/10.26452/ijrps.v11iSP L1.2704.

[26] Kamdi, P.S., and M.S. Deogade. "The Hidden Positive Effects of Covid-19 Pandemic." International Journal of Research in Pharmaceutical Sciences 11, no. Special Issue 1 (2020): 276-79. https://doi.org/10.26452/ijrps.v11iSP L1.2712. 